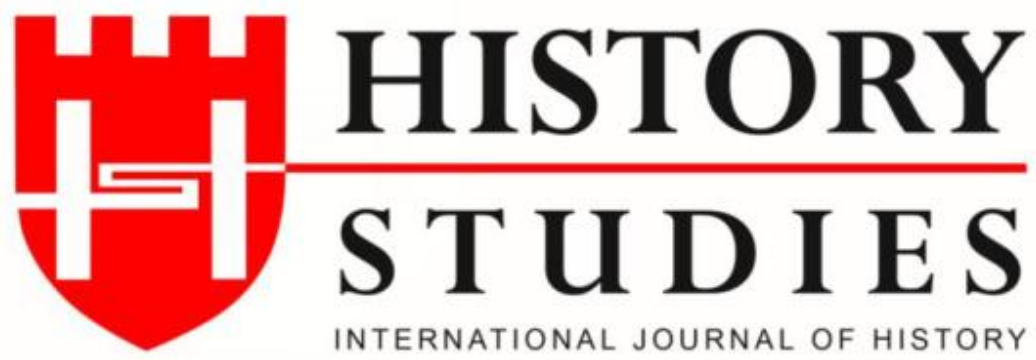

ISSN: 13094173 (Online) 1309 - 4688 (Print)

Volume 8 Issue 4, p. 1-18, December 2016

DOI Number: 10.9737/hist.2017.503

\title{
Çanakkale Cephesinde Günlük Hayat
}

Dally Life in the Gallipoli Front

Yrd. Doç. Dr. Yaşar BAYTAL

Ylldırım Beyazt Üniversitesi - Ankara

\begin{abstract}
Öz: Bu çalı̧̧ma Türk ve Dünya tarihinin seyrini değiştiren Çanakkale Savaşlarındaki askerlerin günlük yaşamlarını konu edinmiştir. Savaşın yaklaşık dokuz ay sürmüş olması, her iki kuvvetin cephedeki durumunu doğrudan etkilemiş̧ir. Bu süre zarfinda siperler askerlerin vazgeçilmez yaşam alanları olmuştur. Siperleri kazmak ve tahkim etmek savaşın getirdiği korunma ihtiyacının bir gereği olsa da siperlerdeki günlük yaşam askerler için oldukça ă̆ırdır. Dokuz ay boyunca askerlerin savaştaki mücadeleleri yanında hayatta kalma mücadelesi de savaşın seyrini değiştiren önemli bir etkendir. Bu çallşmada, Türk ve Müttefik kuvvetlerin savaştaki mücadelelerinden çok hayatta kalma mücadeleleri ele alınmıştır. Zorlu iklim koşullarına karşı mücadele, hastalıklara karşı mücadele, açlık ve susuzluğa karşı mücadele konumuzun ana temasını oluşturmaktadır. Cephedeki bütün bu olumsuzluklar karşısında hayatta kalma mücadelesinde Türk ve Müttefik askerlerin göstermiş oldukları tavır ve davranışlar, örneklerle somutlaştırılmıştır. Teknik ve askeri üstünlüğ̈̈n özellikle bu savaşta tek başına yeterli olmadiğl; cephe gerisinde verilen mücadelenin de savaşın seyrini değiştirebilecek önemli bir unsur olduğu bu çalışmada ortaya konulmuştur.
\end{abstract}

Anahtar Kelimeler: Çanakkale Cephesi, Siper, Asker, Günlük Hayat

Abstract: This study deals with the daily lives of soldiers in the Gallipoli Front during World War I. The battle in the Gallipoli Front lasted for nine months, and during this period, trenches became indispensable living areas for all soldiers. Digging and strengthening trenches were necessary daily activity for protection. This study examines the daily life and struggle in the trenches rather than the battle. Struggle against harsh weather conditions, against diseases, famine and water shortages are the main themes of this study. The study presents that technical and military superiority are not sufficient to win a war; logistic struggle behind the front can change the trajectory of a battle.

Keywords: Gallipoli Front, Trench War, World War I, Daily Life

\section{Giriş}

Çanakkale'de ilk deniz savaşı, 3 Kasım 1914'te İtilaf Devletlerine mensup kruvazörlerin boğazın Anadolu ve Rumeli yakasındaki tabyaları bombalamasıyla başlamıştır. Akdeniz Başkomutanı Amiral Karden'e göre; Boğaz bir ay içinde geçilmiş olacaktı. Bu yüzden İngiliz ve Fransız zurhlıları, Çanakkale boğazına saldırıya geçtiler. Savaşın ilerleyen günlerinde Fransızlar asabiyetlerini, İngilizler ise, soğukkanlılıklarını bu cephede göstermeye başladılar. $\mathrm{Bu}$ anlamda İngiliz gemileri dengeli tahrip atı̧ı yaparken, Fransız gemileri daha fazla ileri atılarak Türk bataryalarını etkisiz hale getirmek ve sonuca bir an önce ulaşmak istiyorlardı. ${ }^{1} 19$ Şubat 1915 'te başlayan bu deniz taarruzuna Türk tabyaları, yoğun topçu ateşiyle karşıllk verdi. İtilaf donanması bu ateş karşısında Mondros'taki üssüne dönmek zorunda kaldı. İtilaf donanması 20, 25 Şubat ve 5 Mart günü Türk tabyalarına yaptıkları saldırılarda ise, ağır hasar

\footnotetext{
${ }^{1}$ Burhan Sayılır, Selanikli Yüzbaşı Hüsnü Efendi’nin Çanakkale Muharebeleri Günlüğü, Grafiker Yayınları, 1. Baskı, Ankara 2014, s. 31.
} 
ve kayıplar aldılar. ${ }^{2}$ İtilaf devletleri en son hücum planını üç tümen halinde tekrar taarruza geçerek başlattılar. Ancak Amiral De Robeck bu savaşta Çanakkale'nin geçilemeyeceğini anladı ve donanmasını geri çekti. Artık savaş karada aylarca sürecek siper savaşına dönüşmüştü. İtilaf devletlerinin 25 Nisan 1915 günü başlattıkları kara harekâtı, Arıburnu, Conkbayırı ve Anafartalar'da Türk kuvvetleri tarafindan durduruldu. İtilaf devletlerinin büyük hezimetiyle sonuçlanan bu cephedeki kara savaşında geri çekilme ise, Aralık ayından itibaren başladı. İngilizler 19-20 Aralık 1915'te Arıburnu, Anafartalar, 8-9 Ocak gecesi Seddülbahir bölgesini boşaltmasıyla Çanakkale muharebeleri son bulmuş oldu. ${ }^{3}$

\section{1-Savaş Öncesinde Müttefiklerin Gözünde Türk İmajı ve Propagandalar}

İlk başlarda nefret tohumlarıyla başlayan bu savaş, daha sonraları centilmenlik savaşı olarak tanımlanan güç mücadelesine dönüştü. Nefret tohumları daha çok Alman ve Alman kökenli olanlara yönelikti. Çünkü Çanakkale'deki çarpışmalar, İtilaf ve İttifak kuvvetlerinin belirleyici gücü olan Almanya arasında olacağı tahmin edilmekteydi. Osmanlı Devletinin savaşa katılması onlar için önemli değildi. İtilaf kuvvetlerine göre; Osmanlılar, Almanların bir piyonu kendi başına hareket edebilecek kapasiteden yoksun bir devlet olarak yorumlanmaktaydı. Hatta Almanların Türkleri korkutarak Onları zorla savaşa sürüklediğine dair görüşler, İtilaf kuvvetleri askerlerinin mektuplarına da yansımıştı. ${ }^{4}$ Savaşın ilerleyen günlerinde İtilaf kuvvetleri mücadelenin Alman kuvvetlerinden çok Türk kuvvetlerine karşı olduğunu gördüler.

Saf ve idealist düşüncelerle cepheye dahil olan acemi askerler, savaşın kısa sürede kendi lehlerine sonuçlanacağını; tatil havasında geçeceğini düşünüyorlardı. Müttefik askerlerin farklı beklentilerini şu şekilde sıralamak mümkündür:

Öncelikle Avrupa'da, Fransa'da ya da Belçika'da Almanya'ya karşı savaşıp İngiltere'nin zaferine yardımcı olunacaktır. Daha sonra savaş bitince, Anavatan İngiltere'de ve hem de Londra'da eşsiz bir Noel geçirilecek, Yeni yılda ise memleketlerine dönüş olacaktır. Savaşta yaşanan kahramanlık öyküleri ile Paris-Londra günleri eşe dosta anlatılacak, fotoğraflar gösterilip, getirilen armağanlar verilecektir. ${ }^{5}$

Müttefik kuvvetlerin özellikle Avustralya ve Yeni Zelanda Ordu Birlikleri, kısaca Anzakların Türkler hakkında bilgileri oldukça sınırlı ve önyargiya dayanıyordu. 1899 yılında yazılmış ders kitabında Türkler, zalim ve cahil olarak tanıtılmıştır. Anzak askerlerinin ilk defa olarak Mısır ve Kahire'de İslam kültürüyle ve Müslümanlarla tanışmalarından dolayı, Türkleri burada yaşayan Müslüman halkla aynı kategoriye koymalarına neden oldu. Aynı şekilde Müttefik askerlerin gözünde de Türkler, diğer Müslüman Araplardan farksızdı. Onların gözünde Arap, Türk, Mısır yerlisi Kıpti ve Felah arasındaki farkı anlamak oldukça zordu. Yine

\footnotetext{
2 “Çanakkale”, Servet-i Fünun, S. 1257, 25 Haziran 1331 (8 Temmuz 1915), s. 130.

3 Mehmet Çevik \& Yavuz Selim Çeloğlu, "Çanakkale Cephesi'nde Türk Ordusunun İaşe ve İkmal Faaliyetleri”, Çanakkale Araştırmaları Türk Yıllı̆̆ı, Yıl: 13, S. 18, Bahar 2015, s. 301.

${ }^{4}$ Yaralanıp tedavi için yattığı Malta'daki hastaneden arkadaşına Avustralyalı çavuş H.D. Collyer, şunları yazmıştı: “...Bir başka sefer bir Türk askeri, yaralı ve yürüyemeyen bir askerimizi buldu. Yaralarını temizleyip sardı. Onu kuytu bir yere yerleştirdi. Arkadaşları tarafından bulunması gecikebilir endişesiyle de yanına, bisküvi ve su biraktı. Gene bir başka Türk yaralı bir askerimizin yarasımı sardı ve hemen gitmesini, aksi takdirde bir Alman subayı gelirse her ikisini de vuracağını söyledi. Tüm şiddet ve felaketlerin sorumlusu Alman köpekleri Türklerin gözünü de iyice korkuttukları içindir ki Türk, yapısının doğal yönlerini bizlere serbestçe gösteremiyor... Diyordu. Yeni Zelandal, 1894 doğumlu Russel John James WEIR ise; “...Onların dürüst, Almanlardan daha dürüst savaşçı olduklarmı düşünüyorum. Ayrıca bu savaşı, istememelerine rağmen, Almanlar tarafindan sokulduklarını düşünüyorum..." Sözleriyle Collyer ile aynı fikirde olduklarımı gösteriyordu. A. Mete Tunçoku, Anzakların Kaleminden Mehmetçik, Atatürk, Dil ve Tarih Yüksek Kurumu Atatürk Araştırma Merkezi Yayınları, Ankara, 2000, s. 99-100, 143.

${ }^{5}$ Age, s. 32.
} 
o günlerde bir Müslüman adı olan "Abdullah" adının kısaltılmışı "Abdul”, Türklerin takma adı haline geldi. Öyle ki Müttefik kuvvetler içinde yer alan Anzaklar, daha sonra Çanakkale Savaşlarında Türk askeri hakkında bu isimle şïler yazıp, öyküler anlattılar ve karikatürler çizdiler. Diğer yandan Müttefik askerlerin Kahire'de bulundukları günlerde, bu genel imaja bir de, "fakir, zavallı ve hileci" gibi olumsuz sıfatlar eklenecektir.

Müttefik kuvvetlerin, Türkler hakkında "zayıf, zavallı" imajının oluşmasında Türklerin Süveyş Kanalına saldırı sonrasında aldı̆̆ı yenilginin de etkisi vardır. Balkan Savaşlarından yeni çıkmış yorgun, düzensiz ve silah donanımı bakımından yetersiz olan Türk birlikleri, Kanal'daki çarpışmalarda başarısız olmuşlar ve ağır kayıplar vererek geri çekilmek zorunda kalmışlardır. Anzakların da dahil olduğu İtilaf kuvvetlerinin Türkler karşısında bu kadar kolay başarı kazanmaları, bu kuvvetleri oldukça şaşırtmıştır. Savaşın daha ilk karşılaşmasında, böylesine kolay bir şekilde "tepeleyiverdikleri" Türk askeri Abdul, artık onlar için kolay bir lokmaydı. Böylece İtilaf kuvvetleri Çanakkale’ye gelmeden önce Türkleri kolay bir şekilde yeneceklerini düşünmüşlerdir. Kanal harekâtındaki başarısızlık sonrasında, Türk askerlerinin genel özelliklerine bir de "zayıf, zavallı" sıfatını ekleyerek Türkleri zayıf ve korkak bir düşman olarak göreceklerdir. ${ }^{7}$

O günlerde, Avustralya, Yeni Zelanda ve Batı gazetelerinde Türkler hakkında çıkan olumsuz propaganda yazıları, buralardaki kamuoyunu etkilediği gibi, buralardan Çanakkale cephesine gelen askerleri de etkilemiştir. $\mathrm{O}$ dönemin gazetelerinde Türkler hakkında çıkan yazı ve haberlerde; "Türkler Hıristiyanları toptan öldürüyor, kadınlara tecavüz ediyor, Türk askerleri, savaş esirlerine çok kötü işkenceler uyguluyor" gibi ifadelere yer verilmiştir. Bu haberlerin Atina, Selanik ve İstanbul'daki gizli kaynaklara dayandırılmış olması, Batı kamuoyunu Türkler hakkında kötü imaj bıraktı̆ğ gibi Gelibolu'ya giderek Türklerle çarpışacaklarını öğrenen Anzaklar ve özellikle geride bıraktıkları aileleri üzerinde olumsuz yargıların gelişmesine yol açmıştır. ${ }^{8}$

İngilizlerin, Türklerin ilkel ve barbar oldukları, esirleri parçalayarak öldürdükleri ${ }^{9}$ propagandasına karşılık, Osmanlı devleti daha çok Almanlardan öğrendikleri şekliyle karşı propaganda faaliyetlerini yürütmüşlerdir. İtilaf devletlerinin askerler üzerindeki psikolojik faaliyetlerinin ana harekât noktası bildiri atmak olduğundan, Osmanlı devleti de 12 Mayıs 1915'te Enver Paşa'nın ve Von Uzedum Paşa'nın talimatıyla İngilizce, Fransızca, Urduca, Gurka dili ve genel olarak Hint lisanında bildiriler basılıp düşman hatlarına atılmıştır. İngiliz, Avustralyalı, Zelandalı ve Hintlilere hitaben yazılan beyannamede Türklerin esirlere uyguladıkları iyi muamele anlatılarak Türk misafirperverliği hakkında bilgi verilmiştir. $\mathrm{Bu}$ beyannameler, Harp Mecmuasında çıkan, iyi beslenmiş ve temiz giyimli esir resimleriyle de desteklenmiştir. ${ }^{10}$ Ancak İtilaf devletlerinin gerek uçaklarla gerekse balonlarla yapmış oldukları bu tür propaganda faaliyetleri karşısında Osmanlı devletinin yaptıkları oldukça sönük kalmıştır. ${ }^{11}$

\footnotetext{
${ }^{6}$ Burhan Sayılır, "Çanakkale Savaşları'nda Yer Alan İtilâf Askerlerinin Dini-Etnik Yapısı ve Sahip Oldukları Türk İmajı", OTAM, Ankara Üniversitesi Osmanlı Tarihi Araştırma ve Uygulama Merkezi Dergisi, S: 18, 2005, s. 325. Tunçoku, age, 36-37.

${ }^{7}$ Tunçoku, age, s. 37.

${ }^{8}$ Age, s. 39.

${ }^{9}$ Sayllir, agm, s. 325 .

${ }^{10}$ Harp Mecmuasl, Y1l: 1, S: 8, s. 128; S: 2, s. 32; S: 9, s. 144; Hasan Babacan, "Enver Paşa", Türkler, C. 11, Yeni Türkiye Yayınları, Ankara 2002, s.269.

${ }^{11}$ Cafer Ulu, "Çanakkale Muharebeleri Sirasında Basının Propaganda Aracı Olarak Kullanılması: Harp Mecmuası Örneği’, Çanakkale Araştırmaları Türk Yıllı̆̆ı, Yıl: 10, S. 12, Bahar 2012, s. 65-66.
} 
İtilaf devletlerinin savaşı kazanacaklarına dair inançları o kadar güçlüydü ki bu durum propagandalarına da yansımıştır. $\mathrm{Bu}$ propagandalardan veya açılamalardan bazılarında Osmanlı devletini küçümseyen veya aşağllayan ifadelere yer vermişlerdi. Örneğin dönemin İngiliz savaş bakanı Kitchener; "Hindistan, Türkiye'yi bir eli arkasında bağlı olarak yenebilir" diyordu. ${ }^{12}$ Çünkü İngiltere'ye göre; Osmanlı devleti çökmek üzereydi ve onlar için Çanakkale cephesinde birkaç gün içinde galibiyet elde etmek hiç zor değildi. Hatta Kitchner daha da ileri giderek bizzat kendisinin atadı̆̆ Sefer Komutanı General Hamilton'a; "Donanma, Çanakkale boğazını aşar, İstanbul kendiliğinden teslim olur ve siz başarıya ulaşırsanız, bu bir muharebenin galibiyeti olacaktır." Diyerek İngiltere için Çanakkale cephesinin İstanbul'u ele geçirmek için kilit rol oynadığı vurgusunu yapmış oluyordu. ${ }^{13}$ Çanakkale Cephesinde Müttefiklerin hedefinin İstanbul olduğu Hamilton'un Gelibolu günlüğüne ise, şu şekilde yansımıştır:

Ümit ediyor ve inanıyorum ki, geleceğin harp okulu öğrencileri büyük bir imparatorluğu harakiri yapmaya mecbur bırakmak için, neden bu kıraç, değersiz kayalıkları üzerinde, eteklerinde sıkıştığımızı değerlendirebileceklerdir. Biz bu kayalıklarda hançerimizi Osmanlı Sultanının kara kalbine sapladık. Yalnız, hançer etini deldi. Yarasından yeni yeni kan akmaya başladı. Her gün ölümden kurtulmak için debeleniyor. Biz, bir metre daha ilerleyemesek dahi, Halifenin canını alınıncaya kadar, kanı bu kaba akıtacaktır. ${ }^{14}$

Amaç ve ideallerle iyi motive olmuş İtilaf kuvvetleri, Çanakkale Cephesindeki plan ve hazırlıklarını Türklerden çok Almanlara göre yapmışlardı. İtilaf devletlerinin, Türkiye ve Türklerin Çanakkale'deki askeri ve stratejik mevkileri hakkında yeterli bilgiye sahip değildiler. ${ }^{15}$ Silahlı kuvvetler müsşterek gizli raporunun 1919 'da düpedüz itiraf ettiği gibi; "harekâtın yürütülmesi için lüzumlu personel ve malzemeyi”" sağlayacak bir teşkilat mevcut değildi”, daha da önemlisi Müttefiklerin deniz ve kara kurmay heyetlerinin üst kademeleri arasındaki uyuşmazlık, Çanakkale'de iyice kendini belli etti. ${ }^{16}$ İşte bu ortamda Kurmay Heyetinin Türk kuvvetlerini değerlendirme işi, bir takım tahminlerde bulunmaktan ileriye gidemedi. Müttefikler, Çanakkale bölgesindeki Türk kuvvetlerinin toplamı 170.000 kişi kadar olduğu tahmin etmekteydiler. Bu kuvvetlerin 40.000 ile 80.000 arası Gelibolu Yarımadasında,

\footnotetext{
${ }^{12}$ Çanakkale Cephesinde İtilaf kuvvetlerinin ağır yenilgisinden sonra Kitchener, en çok eleştirilen ve hatta alay edilen kişilerden biri olmuştur. Eleştirilerin birinde şu ifadelere yer verilmiştir: “...Kitchener, İstanbul elçisi atansayd, Türkiye'yi harbe girmekten menederdi. Bu konuda hiç şüphesi yoktu. Ne Enver Paşa, ne de Talat Paşa, Onu kızdırmağa cesaret edemezlerdi. İleri sürdükleri fikirler düpedüz gülünçtü. Belki onu arkadan vurmağa cesaret edebilirlerdi; fakat katiyen yüz yüze gelip ellerindeki harp ilanını açıklayamazlardı. Kitchener Doğu'ya dair ileri sürdüğü fikirleriyle, emsalsizdi. O yüzden, birçok amatör fikirlerine bakarak onu Harbiye Nezareti'ne getirdik ve kendisine muazzam destek olarak yakınlk gösterdik. Evet, en mükemmel, yetişmiş uzmanlarımızı atıp Kitchener'i çok güçlü bir makineymiş gibi, o makama oturttuk. Sonunda bütün murakabeyi kaybettik; ayarlayıcılar, emniyet sübapları elimizden gitti. Şimdi ne harikalar yaratmak üzere çalışı̆̆ııı görmekteydik!” Ian Hamilton, Gelibolu Günlüğ̈̈, (Çev: Osman Öndeş), Hürriyet Yayınları, 1. Baskı, İstanbul,1972, s. 17-18.

${ }^{13}$ Age, s. 19-20.

${ }^{14}$ Age, s. 192-193.

${ }^{15}$ C.F. Aspinall Oglander, Büyük Harbin Tarihi Çanakkale Gelibolu Askeri Harekatı, (Yayına Hazırlayan: Metin Martı), C: II, Arma Yayınları, 2. Baskı, İstanbul, 2005, 446-447.

${ }^{16}$ Paris’te Çanakkale seferinin kısa zamanda Balkan devletlerini ve İtalya'yı savaşa girmek zorunda bırakacağı sanıllyordu. Ancak şimdiye kadar bu ülkelerden hiç birisi İtilaf devletlerine katılmamıştır. Bu yüzden Fransız Dış işleri Bakanlı̆ğ salonunda, İngilizlerin bu işi yeterince düşünüp hazırlanmadan atıldıkları ve uygun firsatlar kollamadan hemen harekete geçtikleri için sonuç alamadıkları söyleniyordu. Bakanlık salonunda sık sık "bu iş iyi gitmiyor", "bizi üzen konular var" diye sesler yankılanıordu. Bkz. George H. Cassar, Çanakkale ve Fransızlar, (Türkçesi: Nejat Dalay), Milliyet Yayınları, 1. Baskı, Ankara, 1974, s. 201-202. Ayrıca bkz. Servet Avşar, Hasan Babacan (Haz.), Miralay Süleyman Şakir, Cepheden Hatıralar Altıncı Fırka Çanakkale Harbinde, Vadi Yayınları, Ankara 2006, s.123-150.
} 
30.000 'i Asya yakasmda, 60.000 'i ise, ihtiyatta bulunmaktayd $1 .{ }^{17}$ Bütün ihtimalleri hesaplayan Kurmay Heyetinin ordu karaya ayak basınca, kullanacağı su veya yollar gibi basit konular hakkında bilgisi oldukça smırlıydı. Suyun az olacağı tahmin edildiğinden, tatlı su taşımak üzere tulumlar, su tankları, gaz tenekeleri ve akla gelebilen her türlü kap bulmak için bütün Mısır taranmış; ayrıca bir su taktir gemisi ile bir su tankeri kiralanmıştır. Yolların da bozuk olacağı tahmin edilmişti, ancak eldeki sandalların sınırlı sayıda olması yüzünden ilk çıkarmalardan hemen sonra sahile işe yarayacak sayıda at ve yem vs. göndermek mümkün olmayacak ve bunun neticesinde her şeyin elle taşınması icap edecektir. Bu durum bir süre sonra anlaşılmasına rağmen, önlem almak için artık geç kalınmış; topçunun karaya çıkma programları bu yüzden altüst olmuştur. ${ }^{18}$

İtilaf güçlerinin Türkleri küçümseyen ön yargılı tutumları ve savaşı kesin olarak kazanacaklarına dair olan inançları, savaşın başında onları motive eden önemli bir güçtü. Müttefiklerin, Türkleri yeneceklerine dair olan kesin kanıları öyle güçlüydü ki bu durum Hamilton'un Gelibolu Günlüğüne şu şekilde yansımıştır:

Enver Paşa, Anzac'ları yalnız bırakmak istemiyor!! Halbuki biz onun ensesine çok yakınız. Çanakkale Boğazının en dar geçidinde... Yani Enver, en iyi ordularını, genellikle denizden naklederek bu bölgeye getirmek isteyecek ama denizaltı gemilerimiz, havuzda anaç ördek farkına varmadan yavrularını kapan kartallar gibi, zaten düşmanın cephane yiyecek, giyecek ve asker yüklü konvoylarının \% 25'ini avlamakta. Türkler bizi denize püskürteyim derken, başaramayacakları bu iş yüzünden tüm takatlerini tüketip ölecekler. ${ }^{19}$

Ancak bu düşünce, İtilaf güçlerinin yumuşak karnını oluşturuyordu. Çünkü Türklere karşı besledikleri ön yargı ve savaşı kolayca kazanabileceklerine dair olan inançları, Çanakkale'de ummadıkları direnişle karşılaşınca hezimete dönüşecektir.

\section{2-Siperlerde Günlük Hayat ve Hayatta Kalma Mücadelesi}

İtilaf devletleri, Çanakkale'de savaşı donanma savaşı olacağını ve güçlü donanmalarıyla savaşı kısa sürede kazanacaklarına inandılar. Ancak Osmanlı Ordusu, tehlikenin boğazdan gelebileceğini bildiğinden boğaz tahkimine çok büyük önem verdi. ${ }^{20}$ Ayrıca Çanakkale'de İtilaf donanması tehlikesinin belirmesine karşılık Alman kurmay subayları da konuya sıkı sıkıya bağlanmış ve ağır savunma mevzileri inşa olunmuştur. Türk siper ve mevzilerinin mahirane tabya edilişi, Hamilton'un günlüğüne de yansıdığı gibi İtilaf kuvvetlerini oldukça şaşırtmıştı. ${ }^{21} \mathrm{Bu}$ bataryaların günden güne artması ve isabetli atışları sayesinde İtilaf donanması, Çanakkale'de ağır yenilgiler alarak geri çekilmek zorunda kaldı. Denizde alınan yenilgi ve durum hakkında, Winston Churchill ile kardeşi John Churchill arasında geçen yazışmalardan da açıkça anlaşılmaktadır. Mektupta şu ifadelere yer verilmişti:

\footnotetext{
17 Robert Rhodes James, Gelibolu Harekâtı, (Tercüme Eden: Halûk V. Saltkgil), ilk Baskı, Belge Yayınları, İstanbul Matbaası, 1967, s. 114-115. Çıkarma subayı Charles Carby Dix'in Eşine yolladığı mektupta Gelibolu'daki Türk ve İtilaf kuvvetlerinin sayılarını şu şekilde yazmıştır: “...Durum aynen şöyle: Yarımadanın güney ucuna 40.000 asker çıkardık. 50.000 Türk’e karşı zorlu bir mücadele içindeler. Fransa'da bulunmuş subaylar, buradaki Türk savunmasının, oradaki Alman savunmasından çok daha güçlüdür...” Mete Tunçoku-Cemalettin Taşkıran, Çanakkale, Churchill ve Anzaklar, Genelkurmay Basımevi, Ankara, 2000, s. 75.

18 İtilaf devletlerinin Çanakkale ve Türkler hakkındaki bilgisizlik ve ön yargıdan dolayı düştükleri kötü durum Hamilton'un ilk raporunda şöyle yansımıştır: "Tarif ettiğim harekât sahasında bir ordunun karaya çıkarılması...belki XerXes'in meşum efsanelerindekiler müstesna askeri tarihte emsali görülmemiş zorluklara mucip oldu..." James, age, s. 114-115.

${ }^{19}$ Hamilton, age, s. 193.

${ }^{20}$ Tunçoku-Taşkiran, age, s. 61.

${ }^{21}$ Hamilton, age, s. 25.
} 
Bouvet, 700 kişiyle birlikte batmıştı! Çok coşkulu ve heyecanlı bir günün ne korkunç bir bitişiydi bu! Gemilerin boğaza saldırışı harika bir manzaraydı. Savaş gemileri Asya kıtalarına sokulmuş bir şekilde, sürekli bombardıman ediyorlardı. Ancak, Queen Elizabeth ilerlemiş ve boğazın ortasında, yan dönmüştür. Çok etkileyici görünüyor ve ilk baksşta dikkat çekiyordu. Heybetli büyük topları, bu tablonun ana noktasinı oluşturuyordu. ${ }^{22}$

İtilaf donanmasının denizde aldığı yenilgi, savaşın sonu değildi; asıl savaş 25 Nisan 1915 tarihinde başlayan kara savaşlarında verildi. İki kuvvet arasında aylarca süren karadaki mücadele aynı zamanda hayatta kalma mücadelesiydi. Aylarca süren savaşta askerlerin yaşam alanları çoğunlukla siperlerdi. Artık siperler, düşmana karşı verilen saldırı veya savunma mücadele alanı olmanın yanı sıra günlük ihtiyaçlarının çoğunu karşılandığı mekânlar haline gelmiştir. Öyle ki Türk siperleri, mıntıkanın genişliğine ve birbirine girift olmasına rağmen, yön gösteren levhalar, krokiler vasitasıyla insanlar, içinde kaybolmadan, şaşırmadan ilerliyorlar, ${ }^{23}$ günlerce siperlerde yaşamlarmı sürdürüyorlardı.

Çanakkale Savaşları iki ordunun galip gelme mücadelesiydi. Ancak hayatta kalma mücadelesi de savaşın seyrini değiştirebilecek önemli bir etkendi. Cephe gerisinde askerlerin günlük yiyecek, içecek ihtiyaçları yanında temizlik ihtiyaçlarının karşılanması her iki kuvvet açısından oldukça zordur. Askerlerin sağlkklarının korunması her şeyden önce belirtilen ihtiyaçların düzenli olarak karşılanmasına bağlıydı. Siperlerde kısıtlı miktarda verilen su ve yiyecek askerlerin savaşma kabiliyet ve gücünü zayıflattı̆̆ı gibi vücut direncinin azalmasına ve dolayısıyla bazı hastalıkların askerlerde yaygın olarak görülmesine neden oldu. İtilaf kuvvetlerinden bir subay, yiyecek kitlığından muzdarip askerlerin halini hatıra defterine şu şekilde yazmıştır:

Bir önceki gecenin üstüne, bir de bütün gün pek fazla yiyecek bulamayınca, erler artık oldukça hırpalanmışlardı, her yerde uyuyorlar ve yıkılıp kaliyorlardı. Hatta bu yüzden bazı kayıplar bile verdik. Gittiğimiz yere, kim bilir ne zaman varınca, bir dinlenme yerine gönderildik; burası karla örtülü kum tepelerinden ibaret ıssız bir saha idi, şurada burada bir cins karaçalı kümeleri vardı. Son döküntüyü de içeri güttükten sonra, yere uzanı ölmeyi istedim. ${ }^{24}$

Cephede gıda temini ve gidaların korunması oldukça zordu. Özellikle sıcak günlerde gıdalar, hızlı bir şekilde bozuluyor; yenilmesi imkânsız hale geliyordu. Bu durum, her iki kuvvetin askerlerinin yaşadığı önemli bir sorundu. Tahıl, kurutulmuş gidalar ve konserve türü yiyecekler, askerlerin tükettiği önemli yiyecek maddeleri arasındaydı. Yeni Zelandalı Dan Curham'da anılarında, siperlerdeki sefil ve inanılmaz yaşımı şu şekilde anlatmıştır:

Tüm yiyeceğimiz biftek ve sert-kuru bisküitten oluşuyordu. Birçoğumuz bisküit yerken dişini kırıyordu. Sebze, tereyağı, süt ya da gerçek ekmek yoktu. Su sadece yıkama, pişirme ve içme için, kısıtlı olarak vardı. ${ }^{25}$

Osmanlı Ordusu, Balkan savaşlarından sonra iaşe meselesine önem vermiş olmasına ve erzakın cephelere ulaştırılması için önemli yerlere ambarlar tesis etmesine ${ }^{26}$ rağmen, gıdaların

\footnotetext{
${ }^{22}$ Tunçoku-Cemalettin Taşkıran, age, s. 61; Hasan Babacan vd. (Haz.), Bolvadinli Mehmet Sinan Bey'in Harp Hatıraları Mehmet Sinan Özgen, İşbankası Yayınları, İstanbul 2011, s.29-32

${ }^{23}$ Münim Mustafa, Cepheden Cepheye, Ege Basimevi, C: I, İstanbul, 1940, s. 137.

${ }^{24}$ James, age, s. 487-488.

${ }^{25}$ Tunçoku, age, s. 91.

${ }^{26}$ Yücel Özkaya, "Türk ve Dünya Basınında Çanakkale Savaşları", Atatürk Araştırma Merkezi Dergisi, C: XIII, S: 34, Mart 1996, s. 297.
} 
cepheye ulaştırılması ve korunması konusunda bazı sıkıntılar yaşamaktaydı. ${ }^{27}$ Gıda temini konusunda bazen halktan ayni ve nakdi yardım toplamak için dönemin gazeteleri, farklı başlıklar ile yardım kampanyaları düzenlediler. ${ }^{28}$ Siper hayatında basit yiyeceklerin ne kadar önemli olduğunu yedek subay olarak görev yapan Münim Mustafa ${ }^{29}$ cephedeki anılarında mevcut durumu şu şekilde ifade etmiştir:

Orada bulunduğumuz müddet zarfinda gözümüzde tüten şeylerden biri de şeker ve sirke idi...Ah bir damla sirke...Bir parça şeker!.. Ne enfes şeymiş!.. Dünyanın bu nefis gidalarını görmek, kokusunu duymak ta yetişir! Ah bir tabak salata! ${ }^{30}$

Ancak cephede savaşan askerlerin bu tür yiyecekleri elde etmesi oldukça güç görünüyordu. Özellikle yaz aylarında gıdaların korunması ve siperlerde yemek yemek bir süre sonra imkânsız hale gelecektir.

Diğer yandan haziran ve temmuz aylarındaki aşırı sıcaklar dayanılmaz bir hal almış; acele şekilde gömülen askerler toprak altında kokmaya başlamıştır. Ayrıca gömülemeyen at, katır gibi hayvan cesetleri denizde yüzüyor; sıcağın da etkisiyle etrafa keskin, korkunç harp ve ölüm kokusu saçıyordu. ${ }^{31}$ Ancak yemek yenilmesini imkânsız hale getiren bu kokudan ziyade cephedeki askerleri en çok etkileyen sineklerdi. Kıyıda hayvan leşlerinden dolayı yağ bağlamış yeşil ve karasinekler bir afet halinde cepheye ve siperlere çökmüş durumdaydı. Her türlü ortamda bulunan bu sinekler, askerlerin hayatını cehenneme çevirmiş durumdaydılar. $\mathrm{Bu}$ ortamda askerler, sineklere maruz kalmamak için yemeklerini gruplar halinde yemek zorunda kaldılar. Genellikle ikişerli grup halinde yenilen yemekte bir asker yemek yerken diğeri onu bekler ve onun yemeğindeki sinekleri kovalardı. Yoksa bütün sinekler yemek içerisine dolar; yemek yenilemez hale gelirdi. ${ }^{32}$ Sineklerle baş etmenin ve daha rahat yemek yemenin başka pratik yöntemleri Türk siperlerinde başarılı bir şekilde uygulanmıştır. $\mathrm{O}$ yöntem, İstanbul'dan getirilen cibinliklerin altına girerek sineklerden korunarak yemeklerin yenilmesiydi. Askerler sefertasına aldıkları yemekleri cibinliklerin altına girerek kısa sürede de olsa sineklerden uzak yemek yeme imkânına kavuşmuş oldular. ${ }^{33}$ Sineklerden korunmak adına alınan bütün bu önlemlere rağmen, etrafta keskin ve pis koku yüzünden askerlerin yemek yemeleri oldukça güçtür. $\mathrm{Bu}$ yüzden her iki ordunun takati ve direnme gücü zayıflamış; hatta gidasızlık yüzünden ölümler gerçekleşmiştir. Koku ve pis ortam gibi savaşın getirdiği zorlu şartlarından askerler uzak kalamayacağına göre, cephedeki koşullar, askerlerin davranışlarını doğrudan etkiler hale gelmiştir.

Hayatın tabii şekli bozulunca, uykusuzluk, düzensiz yaşamak, her an tehlike altında bulunmak, his ve ihtimalleri işin içine karışınca bazı şeylere karşı ihtiras ve arzu artmakta ve hatta gülünç gelebilecek en basit madde veya bir olay dahi siperdeki hayat akışını değiştirebilmekteydi. Bu anlamda cephedeki koşulları unutturmak ve askerlerin geçici de olsa

\footnotetext{
27 Ordunun gıda ihtiyacının olağanüstü şartlara rağmen zamanında ve düzenli olarak karşılanması hususunda üç temel problem karşlaşıldı. Bunlar; ordunun iaşe ihtiyacının tespit edilerek temin edilmesi, depolanması ve ordu bölgesine sevk ve dağıtımı meseleleridir. Çevik \& Çeloğlu, agm, s. 302. Ayrıca bkz. Muhammet Erat, "Çanakkale Savaşı'nda İaşe Problemi”, Çanakkale Araştırmaları Türk Yıllı̆̆ı, Yı1: 1, S: 1, Mart 2003, s. 114-133.

${ }^{28}$ İkdam, 16 Temmuz 1915, s. 1.

29 I. Dünya Savaşı sırasında Hukuk Fakültesi öğrencisi iken ihtiyat zabiti (yedek subay) olarak orduya alınmıştır. Süveyş Kanalı, Çanakkale ve Kafkasya cephelerinde görev aldı. Savaş yıllarında yaşadıklarını yazdı. Bu anılar 1935 yılında Hafta dergisinde tefrika edildi. Daha sonra bazı ilavelerle bu anıları "Cepheden Cepheye" adıyla kitaplaştırıldı.

${ }^{30}$ Münim Mustafa, age, s. 61.

${ }^{31}$ Tunçoku, age, s. 91.

${ }^{32}$ Hidayet Özkök, Çanakkale'den Hicaz'a: Harp Hatıraları, 1. Baskı, Kayseri: İl Kültür Müdürlüğü Yayınları Kayseri, 1992, s. 11-12.

${ }^{33}$ Münim Mustafa, age, s. 60-61.
} 
yemek yerken iştahını artırmak için Türk siperlerinde kulaktan kulağa bir takım rivayetler gelişti. Bu rivayetlerin biri şu şekildeydi:

Bahriye Nazırı Cemal Paşa'nın Mısır seferine giderken, kendisinin yokluğunda, İstanbul'un en büyük otellerinin birinden her gün muntazaman Bahriye Nezaretine getirilmesini emrettiği on iki kişilik ziyafet yemeklerinin şöhretini siperlerde işittikçe, iştahımız kabarıyordu. ${ }^{34}$

$\mathrm{Bu}$ tür rivayetlerin şöhreti duyuldukça iştahlar artıyor; siperlerdeki kötü ortam bir anda unutuluyordu. Pis ve keskin kokunun askerleri etkilememesi için bu tür rivayetler yanında o günün şartlarında pratik çözümler de uygulanmıştı. Etraftaki pis kokudan aciz kalan askerler için bir beyaz bez içerisine dikilmiş olan kâfurun denilen ilaçlı torba siperdeki Türk askerlerin boynuna takılarak askerlerin pis koku hissetmelerinin önüne az da olsa geçilmiş oldu. ${ }^{35}$

Siperlerdeki günlük yaşam için elzem ihtiyaçlarından biri olan su, askerlerin hayatta kalmaları için önemli olduğu kadar temizliklerini yapmak ve dolayısıyla hastalıklardan korunmaları için de önemliydi. Ancak suyun kit oluşu nedeniyle siperlerdeki yaşam çekilmez bir hal almıştır. Siper ortamından dolayı içilecek ve temizlik yapılacak suyun temini ve saklanması oldukça güçtü. Tanımadıkları coğrafyada savaşan İtilaf kuvvetleri askerleri için su temini daha da zordu. Susuzluğun bu askerler arasında ne kadar ciddi boyuta ulaştığını er Thomas Dry adındaki bir Avustralyalı er, şu şekilde anlatmıştır:

Aşağı yukarı on beş gün içecek su ve çay bulamadık. Susuzluğumuz öyle bir fena hal almıştı ki, bir damla su bulabilmek için, başımızın ciddi surette belaya girmesini göze alarak, gece yarısı etraflarına nöbetçiler dikilmiş olan aş̧̧ıların yanına kadar iniyorduk. Derken kar yağınca, onu yedik, ama susuzluğumuzu gidermek için çok yememiz lazım... Artık nereye gidersek gidelim, Gelibolu kadar kötü olamaz.

$\mathrm{Bu}$ ortamda sersemlemiş vaziyette olan müttefik askerlerin birçoğuna göre, Türklerin onları denize dökmelerini önleyecek bir şey kalmamıştır. ${ }^{36}$

Su temini konusunda Türk askerleri daha avantajlı görünüyordu. Çünkü kendi topraklarındaki temiz su kaynaklarını iyi biliyorlardı. Türk askerleri bu cephede savaş başlar başlamaz su kaynaklarının temiz tutulması için gerekli önlemleri de almışlardı. Osmanlı ordu komutanları, askerlerin cepheye sevki sırasında nerelerden geçilecekse o güzergah önceden incelenmekteydi. Askerlerden oluşan bir ekip rast geldikleri çeşme ve kuyu sularını muayene ediyorlardı. Bunların içilecek durumda olanlarının üzerine (içilebilir), içilemeyecek durumda olanların üzerine ise (içilemez) ibaresini yazmışlar; hatta içilmesi sakıncalı olan suların başına bir nöbetçi asker dikerek olası hastalık ve ölümlerin önüne geçmişlerdir. ${ }^{37}$

İçilecek suyun dahi bütün önlemlere rağmen, siperdeki tozlu ortamdan dolayı, beyaz tebeşire benzeyen tortu oluşturarak içilemez hale gelmesi, cephedeki askerlerin hastalanmasına ve takatsiz kalmasına neden oluyordu ${ }^{38}$. Üstelik siperlerde temiz su ve yeterli vaktin olmayışı yüzünden beden ve elbise temizliğinin yapılamaması bazı hastalıklara davetiye çıarıyordu. Cephedeki zorlu hayat mücadelesi içinde bizzat yer alan Münim Mustafa mevcut durumu şu şekilde özetlemiştir:

\footnotetext{
${ }^{34}$ Çanakkale Hatıraları, C. III, (Yayma Hazırlayan: Metin Martı), Arma Yayınları, İstanbul, 2001, s. 384.

${ }^{35}$ Hidayet Özkök, Çanakkale'den Hicaz'a: Harp Hatıralarl, Kayseri: İl Kültür Müdürlüğü Yayınları, 1992, s. 12.

${ }^{36}$ James, age, s. 488-489.

37 "Ahval-i Sihhiye", Ikdam, 16 Temmuz 1915, s. 1.

${ }^{38}$ Çanakkale Hatıralarl, C. III, s. 384.
} 
Bir gün birdenbire doğrularak ceketimin düğmelerini çözmeye başladım. Hani bazan yerde görürsünüz, yuvasına yem taşıyan karıncaların dizisi vardır. Gömleğimin üstünde tıpk1 ona benziyen bir çizgi hasıl olmuş!... O vakit kendimden iğrendim ve düşündüm. ${ }^{39}$

Denize yakın yerde savaş yapılmasına rağmen susuzluktan askerlerin temizliğini yapamaması ne acı şey! Ancak denize döşenecek borularla siperlere kadar ulaştırılması ve askerlerin temizliğinde kullanması mümkün gözükmüyordu. Çünkü savaşın getirdiği güvenlik endişesi ve yıkım bunun imkan dahilinde olmadığını göstermekteydi. ${ }^{40}$ Lekeli humma, bit hastalıkları askerler arasında sıç̧a görülmesi sonrasında portatif çadırlarda sonbaharın serinliğine ve tehlikeli olmasına rağmen, tenekelerde sular isttlarak askerlerin banyo yapmalarına izin ve imkan verilmiştir. Çadırların etrafına ise nöbetçiler yerleştirilerek düşmanın olası uçaklarla yapacakları saldırıyı önceden haber vermeleri sağlanmıştır. ${ }^{41}$

Cephede askerlerin mücadele ettiği sorunlardan biri de salgn hastalkklardı. Cephede en çok sitma ve dizanteri vakalarına rastlanmakta; ölümlerin çoğu da bu hastalklardan ileri geldiği tespit edilmişti. Bazı hastalıklar, önceden tedbir alınarak önlemek mümkündü. Bu konuda en başarılı sonuç Tifüs hastalı̆gna verilen mücadelede elde edilmiştir. ${ }^{42}$ Türk ordusunda müttefik ordusunun aksine bu hastalı̆̆ yakalanan asker sayısı oldukça azdır. Çünkü Türkler, bu hastalı̆̆ın önlenmesi için elbise temizliğine önem vermişler ve imkân olmadığı durumlarda ise, elbiselerin dezenfeksiyonunda sahra firınlarını kullanmışlardır. Türk askerlerinin pratik ve etkili bilgileri sayesinde bu hastalıklardan korunmayı bilmişler; cephedeki bu tür bulaşıcı hastalı̆ın neden olduğu ölümlerin önüne geçebilmişlerdir. ${ }^{43}$ Askerler arasında en sik görülen enfeksiyon hastalı̆̆ından bir diğeri ise, sitma olmuştur. Özellikle Mayıs 1915'te Kumkale bölgesinde ciddi sitma vakaları görülmüş̧ür. Bölgenin sazlık ve bataklık oluşu bu hastalığın yayılmasına neden olmuştur. ${ }^{44}$ Askerler bağışıklık için kolera, çiçek, dizanteri gibi bulaşıcı hastalıklara karşı periyodik olarak aşılanmaktaydılar. Ancak ishal vakaları ve ishalden ölümler, sıkça görülmeye başladığından iki ordu, bulaşıcı hastalıkların önlemek için emir yayınlamıştır. Bu emirde; helaların kireç ve kireç sütü ile dezenfekte edilmesi, bit yoklamaları yaptırılması, içme sularının bulunduğu küplere musluk takılması istenmiştir. ${ }^{45}$ Bunun yanı sira siperlerde mümkün mertebe bütün yiyeceklerin sinek ve tozdan korunması, pişmemiş yiyeceklerin az veya hiç tüketilmemesi konusunda da uyarılar yapılmış olmasına rağmen, siperlerdeki pis ortamdan dolayı özellikle ishal vakalarına oldukça sık rastlanılmakta ve bazen ölümle sonuçlanmaktaydı. Özellikle yabancı bir coğrafyada savaşmanın acemiliğini yaşayan, iklim ve ortam koşullarını iyi bilmeyen Anzak askerleri arasında bu hastalıktan ölüm vakaları oldukça fazlaydı. Bir Avustralyalı askerin yazdı̆̆ına göre; “...devamlı ishalden, yürüyen iskeletlere dönmüş adamları geceleri, nöbette olmadıkları

\footnotetext{
${ }^{39}$ Münim Mustafa, age, s. 105.

40 Münim Mustafa cephedeki anılarında şu ifadelere yer vermişti: “....sağımız ve solumuzdaki denize dört beş kilometre boru uzatarak cenup cephesini tutan dört frrkalk askerin bol su ile yikanması temin edilemez mi? Bu mühim bir iş te değildi. Ufak bir himmet ile sahilden borularla, tonlarla cepheyi suya garketmek kabil iken, susuzluktan yıkanamıyorduk... Bu sebeple harbi kazanan cenup grubunun her an sari bir hastalğa tutulması kabildi. Nitekim Kafkas cephesinde bu facia oldu..." Münim Mustafa, age, s. 105.

${ }^{41}$ Münim Mustafa, age, s. 139.

42 Ikdam, 3 Temmuz 1331 (16 Temmuz 1915), s. 1.

43 Tuncay Yılmazer, "Çanakkale Savaşlar'ında Sağlk Hizmetleri”, Çanakkale Savaşları Tarihi, C. IV, Değişim Yayınları, İstanbul, 2008, s. 2351.

${ }_{45}^{44}$ Age, s. 2351.

${ }^{45}$ Halise Coşkun, "Çanakkale Savaşlarında Sağlk Hizmetleri”, TAF Preventive Medicine Bulletin, Yı1: 2014, C. 13, S: 2, s. 95 .
} 
zaman, pis bir tuvaletin çukurunun yanı başında uyurken bulmak mümkündü..." ${ }^{46}$ Diyordu. Müttefik ordusu sağlık ekipleri, askerlerin maruz kaldıkları hastalıkları önlemede bazı yöntemler geliştirmeye çalıştlar, ama bunda hiç başarılı olamadılar. Anzak kuvveti, haftada yüzde 10 gibi korkunç bir oranda erimeye başladı. Yarımada'daki Müttefik askerlerinden yaklaşık olarak yüzde 80'inin, şu veya bu derecede bir hastalığa yakalanmış olduğu hesaplanmaktaydi. ${ }^{47}$

Yoksul görünümündeki giyecek durumu, özellikle Türk ordusunun sağlk bakımından kritik durumunun ana sebeplerinden biriydi. Düzenli bir giyecek politikası olmadığından, fazla giyeceklerin titizlikle depolanması ve stokların deftere kaydı gibi durumlar söz konusu değildir. Balkan savaşında giyeceklerin fazla miktarda kullanımından dolayı kıtalar, giyecek kıtlığı ile karşı karşıya kalmışlardır. Ülke dışına büyük siparişler verilmesi için gerekli mali imkân olmadığından ordunun büyük bir kısmı üzerinde taşıdıkları giysilerle idare etmek zorundaydılar. Asker için gerekli kayda değer sefer üniformaları olmadığından dolayı askerler ya param parça olmuş, delinmiş kopmuş giyecekler giymek zorunda ${ }^{48}$ ya da herhangi bir depoda aranarak ortaya çıkarılmış olan kendine özgü rengârenk üniformalar giymek zorundaydılar. Ayrıca çizme, iç çamaşır gibi giyecekler de içler acısı bir durum göstermekteydi. Çok sayıda asker iple bağlanmış terlik taşıyordu. Ordunun giyecek bakımından zayıf durumu dönemin gazetelerine de yansımış; terlikçi, manifaturacı gibi esnaflardan nakdi yardım değil de ayni yardımların toplanması konusunda teşvik edilmiştir. $\mathrm{Bu}$ esnafların yapmış oldukları ayni yardımlar dönemin gazetelerinde yayınlanmış diğer esnaflar özendirilmiştir. ${ }^{49}$

Gelibolu'daki savaş şartları korkunçtu. Yaklaşık dokuz ay süren bu savaşta iki kuvvet çarpışmak yanında aşırı sıcak ve soğuk iklim koşullarında hayatta kalma mücadelesi verdiler. Çanakkale cephesindeki savaşın uzun sürmesinden kaynaklı iki kuvvet askerleri aşırı sıcak ve soğuk iklim şartlarından oldukça etkilenmiştir. Temmuz ve ağustos aylarında Arabistan çöllerini aratmayacak kadar yakıcı sıcak askerleri bunaltmış; savaştaki güçlerini kırmıştır. Cephede sıcaktan dolayı askerlerin içine düştüğü durumu dönemin ihtiyat zabiti Münim Mustafa şu şekilde anlatmıştır:

Bir gün siperleri gezerken bir neferimizin kara torpiliyle parçalanan cesedi portatif çadıra bocalanırken gördüğüm vakit ne kadar müteessir olmuştum. Her azası bir parça haline gelmişti... toprağın içindeki darack yollarda, siperlerin içinde yapılan zeminlikler esasen rutubet içinde ve hava almadığı için gündüz güneş vurduğu vakit insan buram buram ter döküyor. Adeta insanı eritecekmiş gibi kavuruyordu. ${ }^{50}$

İnsanların ayakta zor durduğu bu ortamda askerleri ölüm korkusu sarmıştır. Çanakkale cephesinde iklim şartlarından dolayı asıl can kaybı, soğuk kış günlerinde gerçekleşti. Kar ve don, ordunun tepesine bir yumruk gibi indi. Anzak ve Hintlilerden çoğu bundan evvel

\footnotetext{
${ }^{46}$ Ebral Sözüdemir, Anzakların Gözüyle Çanakkale Savaşları, İstanbul Üniversitesi Atatürk İlkeleri ve İnkılap Tarihi Enstitüsü, Yayınlanmamış Yüksek Lisans Tezi, İstanbul, 2006, s. 109.

${ }_{47}^{4}$ Agt, s. 109.

${ }^{48}$ Münim Mustafa, age, s. 139.

49 İkdam gazetesi Çanakkale Mektubu yazısında şu ifadeler kullanarak yardımları özendirmiştir. “...kundurasının bağı kopmuş bir askerin eline bir bağ veyahut ip geçirememesi, çakısını kaybetmiş tırnağını kesecek bir adamın bundan mahrum oluşu ne kadar güç bir şeydir. İşte böyle zamanlarda vatandan gelen hediyelerle bu gibi ihtiyaçların izale edilmesi askerimizin ruhunda pek büyük sevinçler, memnuniyetler hasıl ediyor. Hattı zatında on paralık kıymeti olan bir çift bağı, kıymeti takdir olunamayacak derecede nadide bir şey gibi makbule geçiyor...” İkdam, 16 Temmuz 1915, s. 1. Ayrıca esnafların yaptıkları yardımlar için bkz. Ikdam, 13 Mayıs 1915, s. 2; Sabah, 11 Mayıs 1915, s. 1; Sabah, 15 Mayıs 1915, s. 3.

${ }^{50}$ Çanakkale Hatıraları, C. III, s. 418.
}

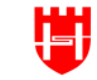

HISTORY STUDIES 
ömürlerinden hiç kar görmediğinden onlar üzerindeki etkisi daha fazla oldu. Soğuk günlerde siperlerdeki askerleri soğuktan koruyan battaniyeler kaskatı donuyor, tüfekler tutukluk yapiyor, nöbetçilerin donarak öldüğ̈̈ görülüyordu. Soğuğun şiddetiyle kendinden geçen ve sersemleyen askerler, bir süre sonra siperlerde donarak hayatlarını kaybetmişlerdi. Hayatta kalanlardan bazısı ise kollarını, bacaklarını hatta aklını kaybederek cepheden ayrılmışlardı. Suvla'da 12.000'den fazla, Anzak'ta yaklaşık 3000, hava şartlarını o derece kötü olmadığı Hellas'ta 1000 'e yakın donma ve soğuktan hastalanma vakası görülmüsşür. Doğrudan doğruya firtına ve tipiden ise, 280 asker hayatını kaybetmiştir. Herefordshire Alayı'ndan bir yüzbaşı, birkaç gün sonra, hatıra defterine şunları kaydetmiştir:

O soğukta, boş mideler üzerindeki tesiri düpedüz müthiş oldu. Yalancı bir sıcaklık içinde, yerlerde yatıyorlardı, birçokları kaputlarını, postallarını ve hatta, Jaketlerini çıkarmışlardı!...Bulduğum bir adamı özellikle hatırlıyorum, üzerinde gömlekle pantolondan başka bir şey yoktu; kaskatı kesilmiş kolunda bir maşrapa tutuyordu, çoktan ölmüştü.

Soğuğun etkisinden geçici süre de olsa kurtulmak için Suvla'da bir takım askerler rom depoların talan edip, tam manasıyla kontrolden çıkmışlard.. ${ }^{51}$ Diğer taraftan iki taraf askerleri soğuğun şiddetinden dolayı, bütün tehlikeleri göze alarak ateş yakarak ısınmaya çalışmışlardı. $\mathrm{O}$ anlar askerlerin gözünde savaştan çok hayatta kalma daha önemli hale gelmiştir.

HISTORY STUDIES

Her mevsimin getirdiği doğal şartlar veya afetler, Çanakkale'deki siper hayatını farkhı şekilde etkiledi. Yazın aşırı sıcağın getirdiği olumsuz koşullar; kışın aşırı soğuğun getirdiği olumsuz koşullar, siperlerdeki askerlerin hayatta kalma veya savaşma gücünü zayıflattı. Bunun dışında ilkbahar ve sonbahar aylarında yağan aşırı yağmurlar, siperlerin içerisine dolarak oraları birer göl haline dönüştürdü. Aşırı yağmurların etkisiyle sağa sola her çukura, zeminliklere seller hücum etmiş; siperler balçk halinde bir çamur deryasına bürünmüştür. ${ }^{52}$ Askerlerin sığınacak yeri, üst başı kalmamış hepsi çamura bulanmıştır. Özellikle Türk siperlerinin daha fazla derin olduğu düşünülünce yağmurla oluşan selin yıkıcı etkisi, Türk siperlerinde daha fazla görüldü. Bütün bu sıkıntılı ortama rağmen, havalar açıldığı vakit güya çamursuz veya ölmek bir muzafferiyetmiş gibi askerlerin yüzü gülmeye ve savaşın getirdiği koşullara ayak uydurmaya devam ettiler. ${ }^{53}$

Bütün bu doğal afet veya şartların getirdiği zorlukları yenmesini bilen ve mücadelesini sürdüren askerleri asıl zorlayan olay ise, özel günlerde ailelerinin yanlarında olmamalarıydı. Dini bayramları siperlerde geçiren Türk askerleri için en buruk günlerden biriydi ve bu günleri askerler, çarpışarak geçirmişlerdi. Münim Mustafa cephede aldığı notlarda savaşın acımasızlı̆̆ını şu ifadelerle vurgulamıştır:

İngilizler her nedense bu gece pek sinirli idiler. Bizim dini bayramımızı bildikleri için maneviyatımızı güya sarsmış olmak için şafaktan itibaren büyük taarruz gününde yaptıkları topçu ateşine benzer bir bombardımana başladılar. Bunlara alş̦ı olduğumuz için pek aldırış etmiyorduk. Bir aralık ateş hafiflemişti. Herkes birbirleri ile bayramlaşmağa başladı. Eller skkılarak, bayram tebrik edilirken, herkesin muhayyilesinden annelerin, sevgililerin hayali geçtiği görülüyor gibi oluyordu. ${ }^{54}$

\footnotetext{
${ }^{51}$ James, age, s. 487-488.

52 James, age, s. 110.

${ }^{53}$ Münim Mustafa, age, s. 130.

${ }^{54}$ Age, s. 130; Ayrıca siperdeki bayramlaşma için bkz. Kanlısırt Günlüğ̈̈ Mehmed Fasih Bey'in Çanakkale Anılarl, (Yayına Yazırlayan: Murat Çulcu), Kaptan Yayıncıllk, İstanbul, 2006, s. 56.
} 


\section{3-Cephe Gerisinde Verilen Mücadele ve Destek}

Çanakkale savaşlarında iki ordunun mücadelesi sadece cephede değil cephe gerisinde birçok alanda verilmiştir. Bu anlamda askerlerin moral ve motivasyonu, iaşenin düzenli sağlanması ve en önemlisi ise, cephede yaralanan askerlerin nakli ve tedavilerinin en iyi şekilde sağlanması gibi konular çok önemliydi. Osmanlı Devleti, Çanakkale cephesinde muharip unsurun ihtiyaçlarını karşılama hususunda diğer cephelere nazaran daha mahirdiler. Bunda 5. Ordunun iaşe bölgesinin ülkenin tarım, sanayi, ulaşım vb. olanaklar açısından en gelişmiş bölgesini içine almasının büyük etkisi vardır. Bununla birlikte cephenin başkent İstanbul'a yakınlı̆̆ ve meydana gelecek başarısızlık devletin bekasını yakından ilgilendirdiğinden bu cepheye, diğer cephelere nispetle daha çok önem verildi. $\mathrm{Bu}$ amaçla devletin tüm olanakları öncelikli olarak bu cepheye aktarıld. ${ }^{55}$

İtilaf güçleri, savaşın başından itibaren kendi askerlerinin morallerini en üst seviyede; Türk askerlerinin morallerini ise en alt düzeyde tutmak için propaganda faaliyetlerine ayrı bir önem vermişlerdir. Propaganda faaliyetlerinde birçok yöntem ve araç kullanan müttefikler, Türk kamuoyunu da etkilemek için bu tür faaliyetleri cephe gerisine taşımışlardır. Müttefik güçler, propaganda faaliyetlerini daha çok maddi ve psikolojik baskıyı ön planda tutarak morallerinin bozulmasını hedeflemişlerdir. Cephede savaşan askerin ailesinden veya çevresinden alacağı küçük bir olumsuz haberlerden aşırı derecede etkilendiği düşünülünce bu tür baskıların savaş stratejisi açısından ne kadar önemli olduğu daha iyi anlaşılacaktır. Müttefikler, Türklere karşı savaştan önce yürüttükleri "barbar, zavalll, Abdul" gibi imajlar, savaşın başından itibaren değişmeye başlamıştır. Artık Türk askerinin direnişini kırarak teslimini sağlayacak ikna ve gerçek dışı haberler yapmaya yöneldiler. $\mathrm{Bu}$ anlamda müttefikler, kendilerinin ne kadar iyi durumda oldukları, yiyecek-içecek, giyecek ve diğer imkânlarının mükemmel olduğu ve teslim olmaları durumunda aynı imkânlara kavuşulacağına dair mektup ve broşürler cephelere atmaya başlamışlardı. Bunlardan birinde; "Esirlere muamele, teslim olmaya çağırı" başlıklı beyannamede, esir düştükleri zaman aç, çıplak, perişan olan Osmanlı askerlerine İngiltere hükümeti tarafindan fevkalade bakıldığı, her türlü ihtiyaçları ve hatta dini vecibelerin yerine getirilmesine dahi riayet edildiği belirtildikten sonra; "esir düşmüş olan arkadaşlarınızın refah hallerine iştirak etmeğe siz de gönüllü olunuz" denilerek Osmanlı askerlerinin İngiliz birliklerine esir olması tavsiye edilmiştir. Yine İngilizler tarafindan bir başka beyanname ise, Haziran 1915'te 57. Alay siperlerine atılmışır. Beyannamede; "Ey asker! ...Bize iltica edecek her Osmanlı askeri için ağuşumuz açıktır....Evlâd-ı "iyalinize bir an evvel kavuşmak için bundan gayri hiçbir çare yoktur." denilmiştir. Ayrıca Osmanlı devletini müttefiki Almanya ile karşıya getirmek için tahrik ve ikna edici propaganda faaliyetleri yürüterek bu iki gücün ayrışmasını amaçlamışlardır. İtilaf devletleri bu propaganda faaliyetlerini yürütürken dönemin imkân ve teknik alt yapılarını çok iyi kullanmışlardır. ${ }^{56}$

Propaganda konusunda diğer ülkelere nazaran geri durumda olan Osmanlı devleti, halkın ve askerlerin okuma yazma durumunu da göz önüne alarak fotoğraf ile propaganda faaliyetinde bulundu. Fotoğraf ile propaganda yayını yapma açısından Harp Mecmuası en iyi örnektir. Bu dergi, devlet ve ordunun ihtişamını, her şeyin yolunda gittiğini halka fotoğraf ve resimlerle duyurmayı, cephede savaşan askerin ve cephe gerisinde halkın moralini yüksek tutmayı temel amaç edinmiştir. Harp Mecmuasının yayınlanmasının temel işlevlerinden bir diğeri ise, görsel malzemeyi nesir ve şïrler eşliğinde sergilemek ve cephelerdeki gelişmeleri

${ }_{56}^{55}$ Çevik \& Çeloğlu, agm, s. 342

56 İtilaf Devletleri, propaganda faaliyetlerini fotoğraf, broşür, kartpostal, beyanname, mektup gibi dokümanları uçak, balon, gemi ve basın yoluyla geniş kitlelere ulaştırmak yanında sigara paketi veya taşa sarıp tel örgüler ile siperlere yakın yerlerde megafonla Türk askerlerine seslenmek gibi klasik yöntemler kullanmışlardır. Ulu, agm,s. 63-64.

\section{Journal of History Studies}


devlet politikası çerçevesinde propagandist bir yaklaşımla okuyucuya aktarmaktı. ${ }^{57}$ Dönemin önemli gazeteleri de Çanakkale'de askerlerin gösterdiği kahramanliklar anlatılarak halktan yardım talep edilmiştir. Dönemin gazetelerinde; "Kahraman Mehmet Çavuş" başlığı Çanakkale kahramanlı̆ı̆ın simgesi haline gelmişs ve "Kahraman Mehmet Çavuş İçin" başlığıla halktan nakdi yardımlar toplanmıştır. ${ }^{59}$

Görüldüğ̈̈ gibi Türk tarafi, Çanakkale'de askerlerin morallerini en iyi durumda tutmak için geleneksel yardımlaşmayı en iyi şekilde uygulamışlardır. Yapılan ziyaretler de askerilerin moralinin en üst seviyede olmasını sağlamışlardır. Örneğin Osmanlı Savaş Bakanı ve Başkomutan vekili Enver Paşa 4 Mayıs 1915 tarihinde Galatasaray Lisesinde tedavi olan yaralı gazileri ziyaret etmesi askerler tarafindan memnunlukla karşılanmıştır. Hastanelerin yetersiz olmasından dolayı İstanbul'daki birçok okul hastanelere dönüştürülerek yaralıların tedavileri için kullanılmıştır. Okul ve hastanelerde birçok gönüllü gibi Enver Paşa'nın eşi Naciye Hanımın da Asker Ailelerine Yardımcı Hanımlar Cemiyetinin kurulmasını sağlayarak bu savaşın halk ile omuz omuza yürütülmesini sağlamıştır. ${ }^{60}$

Yaralıları ziyaret, Türk askerinin cephedeki direnç ve gücünü artırmak için savaş boyunca geleneksel hale gelerek gerçekleşti. Çocuk, genç, yaşl, Müslüman, Gayrimüslim hemen hemen her kesimden insanlar, çeşitli hediyelerle yaralı askerleri ziyaret ederek onlara moral verdiler. Verilen hediyeler arasında; portakal, süt, yumurta gibi yiyecek maddesi yanında Onları onurlandıran yazılı kutular da hediye olarak verildi. ${ }^{61}$ Cephede Türk askerlerinin morallerinin en üst seviyede tutulması için gönderilen hediye ve bağışlar yanında, bazı gazete sahipleri, kendi yayınlarını cepheye ulaştrarak cephedeki subay ve erler tarafından okunmasını sağladılar. Okuma bilmeyen yaralı askerler için günlük gazeteler, okuma yazma bilenler tarafindan okundu. Cephedeki Türk askerlerinin kahramanlikları gazetelerden okunarak yaralıların moralleri en üst düzeyde tutulmaya çalısıld.$^{62}$ Böylece cephede savaşan askerler kendi kahramanliklarına ait yazıları memnuniyetle okuyor veya okutuyordu. $\mathrm{Bu}$ durum, askerler için önemli moral kaynağı haline gelmiş, savaşma gücü ve azmini arttırmıştır.

İtilaf Devletleri askerlerinde ise, savaşın başlangıcındaki moral ve motivasyon kalmamıştır. Beklemedikleri bu direniş karşısında askerlerin moralleri en alt düzeydedir. Cephedeki kötü şartların getirdiği olumsuzluklar askerlere fazlasıyla yansımıştır. John Alien 31 Mayısta, ölümünden bir hafta evvel ailesine şunları yazmışt:

...erler on iki gündür siperlerde. Moralleri sarsılmış durumda. Siperin içinde, ayaklarımızın dibinde inleyip işkence çeken bir adamla arkadaşlık etmek, hiç de hoş değil. On iki gün, on iki gecedir hemen hiç durmadan (çatışıyoruz). Dün ateş siperinden ayrıldıktan sonra sakin bir gün geçirdik Erler bütün gün yaralllardan ve ölülerden konuşup durdular. Sinirlerim bozulmaya başlıyor. Şunu anladım ki her üniforma giyen adam bir kahraman değildir.

\footnotetext{
${ }^{57}$ Agm, s. 73.

${ }^{58}$ Sabah, 6 Mart 1915, s. 4

59 "Kahraman Mehmet Çavuş İçin”, İkdam, 11 Mart 1915, s. 2; Tanin, 10 Mart 1915, s. 4; Sabah, 11 Mart 1915, s. 2.

${ }^{60}$ Nevin Yazıcı, “Çanakkale Savaşı’nda Türk Kadınının Rolü”, Akademik Bakış, C. V, S. 9, Kış 2011, s. 256.

61 "Gazileri Ziyaret", Sabah, 5 Mayıs 1915, s. 2; "Gazilerimizi Ziyaret Hedâyâ", İkdam, 12 Mayıs 1915, s. 2; Lokman Erdemir, "Çanakkale Muharebeleri Sirasında İstanbul'da Yardım Faaliyetleri”, Çanakkale Araştırmaları Türk Ylllı̆̆l, Yıl: 10, S: 12, Bahar 2012, s. 51. "Osmanlı Kadılar Cemiyeti Hayriyesi”, Sabah, 18 Mayıs 1915, s. 2; "Fevkalade Bir Müsamere", Tanin, 2 Haziran 1915, s. 3; "Çanakkale Müdafilerine Müdafaa-i Milliye Cemiyetinin Hediyesi”, Tanin, 26 Subat 1915, s. 1.

${ }^{62}$ İkdam, 16 Temmuz 1915, s. 1.
} 
Yaralanan askerlerin tedavilerinin sağlanması iki ordu için önemli bir diğer sorundu. Bu konuda karşılaşılan en önemli sorunlar arasında yaralıların nakli, yaralılar için yatak ve tıbbi malzemenin karşılanması ile ilgili sorunlardı. Yaralı sayısının fazlalığı, zaman zaman sargı bezi, pamuk gibi hayati önem taşıyan malzemelerin karşılanması konusunda sıkıntıya düşülmüştür. Yaralıların nakli ve tedavileri konusunda müttefik kuvvetler daha başarılıydı. Çünkü müttefik ordusunda yaralıların nakli için motorlu araçlar, tedavileri için doktor ve hastabakıcılar ve modern tıbbi araç-gereçler daha fazlaydı. ${ }^{63}$ Ayrıca yaralılara yardım konusunda Kızılhaç daha deneyimli ve donanımlıydı.

Buna karşın Türk ordusunun ardında, nüfusu azalmış ve müttefikler tarafindan dünya ticaretine hemen hemen kapatılmış, gelişmemiş daha çok deniz ağına sahip bir ülke vardı. Osmanlı Devleti'nin sahip olduğu demiryolu ağı, Fransa, Almanya ve Rusya'daki demiryolu ağlarından farklı olarak askeri amaçlardan çok ticari amaçlar gözetilerek inşa edilmişti. Özellikle kapitülasyonların getirdiği imkânlardan faydalanan yabancı girişimciler tarafindan kar amaçı olarak inşa edilen demiryolları, yalnızca ülkenin ekonomik merkezlerini birbirine bağlamaktaydı. ${ }^{64} \mathrm{Bu}$ nedenle Osmanlı Devleti, Çanakkale Savaşlarında ordu ve malzemelerin nakli için demiryolunun sağladığı imkânları çoğunlukla kullanamadı. Başkent İstanbul'da üretilen ve sevk edilen malzemeler Marmara Denizi'nde pusuya yatmış olan düşman denizaltınlarının saldırısıyla çoğu zaman yok oluyordu. Bu durum, cepheye askeri malzeme ve gıda sevkiyatını önemli ölçüde engellediği gibi tıbbi malzemelerin ve yaralılarını da sevkiyatını sekteye uğratmıştır. ${ }^{65} \mathrm{Bu}$ yüzden sevkiyat özellikle yaralı asker nakli, çoğunlukla bozuk karayolu ile yapılmaktaydı. Ayrıca bakım ve onarımlarını yetersiz olması ve yenilerinin gelmemesinden dolayı hareket edebilen arabaların sayısı sürekli azalmış olduğundan Türk ordusunda askerlerin nakilleri çoğu zaman yük hayvanları vasitasıyla yapılmakta ve nakiller sırasında can kaybı yaşanmaktaydı.

Diğer yandan Ordu için önemli olan istihkam gereçleri, çantalar ve battaniyelerin yeterli miktarda ve çoğu uzunca süre kullanılabilecek durumda olmaması ${ }^{66}$ asker kaybını arttırıyordu. Ayrıca yaralılara müdahale konusundaki bilgisizlik, tıbbi malzeme, doktor ve hemşirelerin azlığı yüzünden birçok yaralı asker ya taşıma esnasında ya da hastanelerde hayatını kaybetti. Yaralı kayıplarının önemli bir nedeni ise, tıbbi müdahalenin yetersizliği yüzünden basit düzeyde yapılmış olmasıydı. Yaralılar için kurulan Seyyar Yaralılar Hastanesi, yeterli donanım ve imkâna sahip değildi. ${ }^{67}$

Yaralıların tedavileri konusunda Gayrimüslim doktorların çabası önemlidir. Hizmetlerinden dolayı liyakat madalyası alan Fransız Doktor, De Lacombe, savaş süresince Türkiye'de kalarak yaralı ve hastaların tedavisinde yer almıştı. Ancak Alman hekimler, Osmanlı'nın müttefiki olmasından dolayı ağırlıktaydılar. Alman askeri heyeti başhekimi Dr. Kolmer, Dr. Bayer, Dr. Petris Gümüşsuyu Hastanesinde, Dr. Peter, Dr. Tucht Bigalı

\footnotetext{
${ }^{63}$ Osmanlı Devleti'nde ilaç endüstrisi yok denecek kadar az olduğundan ilaçların çoğu dış ülkelerden gelmekteydi. Daha savaşın başlangıcında iyot sıkıntısı baş gösterdiği için tentürdiyot kullanımı konusunda dikkatli olunması emredilmiştir. Coşkun, agm, s. 95.

${ }_{65}^{64}$ Çevik \& Çeloğlu, agm, s. 325.

${ }^{65}$ Carl Mühlman, Çanakkale Savaşı, Bir Alman Subayının Anıları, (Tercüme: Sedat Ümran), Timaş Yayınları, İstanbul, 2006, s. 171.

${ }^{66}$ Age, s. 32.

${ }^{67}$ Cemil Conk Paşa Çanakkale hatıralarında çadırlarda verilen sağllk hizmetlerinin yetersizliğini şu cümlelerle vurguluyordu: “...Vakit gece yarısını geçmişti. Sıhhiye bölüğü kumandanı Hamdi ve ikinci tümen Başhekimi Ziya Beylerin çadırlarında misafir edildim. Yarama tekrar pansuman yaptılar. Sabah olmuştu. Saat 11'de sihhiye bölüğünden bindirildiğim araba ile göğsümde yarahı yaftası olduğu halde, Kilidülbahir civarnndaki Seyyar Yaralılar Hastahanesine vardım. Yarallar Hastahanesi büyük büyük ağaçların altına kurulmuş çadırlardan ibaretti. Yaralı kağıdımda şunlar yazılıydı: İsim: Cemil Bey Rütbe Kaymakam...” Çanakkale Hatıraları, C: II, s. 148.
} 
hastanesinde, Dr. Braun 5. Ordu Tıbbi Müşavirliğinde görev almışlardı. ${ }^{68}$ Yaralıların ihtiyaçlarının karşılanmasında gönüllü sivil yardımlar da önemliydi. Terlikçi esnafı, çarşafçı esnası, yorgancı esnafi yaralıların ihtiyaçlarını karşılamada önemli sayıda malzeme bağışı yaptılar. ${ }^{69}$ Bazı gönüllüler ise, yaralılar için tam donanımlı yatakhane malzemesi alarak katkı sağladılar. $\mathrm{Bu}$ yardımlar sadece Müslümanlar tarafından yapılmamaktaydı. Müslüman olmayan Osmanlı vatandaşlarının da cephedeki askerlerin ve yaralıların ihtiyaçlarının karşılanması için maddi destek ve malzeme desteğinde bulunmuşlardır. ${ }^{70}$ Ancak bütün bunlara rağmen, Çanakkale'de Osmanlı ordusundaki asker kaybı, çoğu zaman cephede değil cephe gerisinde yani yaralıların nakilleri sırasında ve tedavilerinin iyi koşullarda yapılmadığı için vermiştir.

\section{Sonuç}

Nihayet savaş sona ermiştir. Bir kez daha Osmanlının payitahtı İstanbul, düşman işgalinden kurtulmuştur. Şehrin kurtuluşu, büyük sevinç ve coşkuyla kutlandı. Çanakkale zaferi sonrasında Padişaha gazilik unvanı verildi ve tuğralarında Reşat yerine Elgazi yazılmaya başlandı. Sultan Reşat Ihlamur köşü̈nde, bütün bakanların da hazır olduğu merasimde Çanakkale Savaşlarında kahramanlık gösteren alayların sancaklarına eli ile Altın imtiyaz madalyası taktı, yeni teşkil edilen alaylara da sancaklarını verdi. ${ }^{71}$

Üzerinden yaklaşık yüzyıl geçmesine rağmen, Çanakkale savaşlarında geçen olay ve

HISTORY STUDIES

olgular canlılı̆̆ını koruyor. İnsanoğlunun en zorlu şartlarda bile bulunduğu ortamda sosyal yaşam alanı inşa etmenin en iyi örneklerinden biri, Çanakkale cephesinde görülmüş oldu. Çanakkale cephesi, her iki kuvvetin savaş yanında hayatta kalma mücadelesinin verildiği bir önemli bir yer oldu. Siperlerdeki zorlu yaşam koşullarına ayak uyduran ve hayatta kalmayı başaran kuvvet, savaşta avantajlı duruma geçebiliyordu. Ancak gerçek olan şu ki savaşta kazanmak veya kaybetmek arasındaki çizgi, Çanakkale cephesinde yok gibiydi. Savaşta iki kuvveti dengeleyen unsur ise siperlerdeki zorlu yaşam koşullarına ayak uydurmak ve hayatta kalmaktı. Türk askerleri, bu yaşam koşullarına ayak uydurmayı ve hayatta kalmayı başarabildiler. İtilaf devletlerinin teknik ve askeri üstünlüğü, Çanakkale Cephesinde Türk ordusunun deniz ve siperlerde vermiş oldukları olağanüstü mücadeleyle bertaraf edildi.

25 Nisan 1915 akşamı kazılmaya başlanan siperler, yaklaşı dokuz ay sonra savaşan askerlerin mezarı oldu. Artık savaş, yerini çeşitli efsane ve gerçeklerle yoğrulmuş kahramanlık öykülerine bıraktı. Bu öykülerin çoğu, belki Çanakkale'de çarpışan askerlerin günlük hayatlarının bir parçasıydı. Türk askerleri için bu cephe, Kurtuluş Savaşında verilecek mücadelenin ilk tecrübesiydi. Çanakkale Savaşı, I. Dünya Savaşının gidişatını değiştirmişti. Ancak asıl değişim I. Dünya Savaşı sonrası kurulan yeni denge ve sistemlerde yaşandı. Çanakkale Savaşlarında müttefiklerinden yeterli destek alamayan Sovyetler Birliği komünist rejimi benimseyerek I. Dünya savaşından çekilmiş, Kurtuluş Savaşında bağımsızlık mücadelesi veren Türklere destek vermiştir. Mücadele sonrasında bağımsız Türkiye kurulmuş; Batılı demokratik devletler içerisinde yerini almışıtır.

\footnotetext{
68 Ahmet Esenkaya, "Çanakkale Muharebelerinde Cephede ve Cephe Dışında Sağlık Hizmetleri”, Çanakkale Araştırmaları Türk Yıllığ l, S: 10-11, s. 57; Yılmazer, agm, s. 2353.

69 "Gazilerimizi Ziyaret", Sabah, 11 Mayıs 1915, s. 1.

70 "Gazilerimiz İçin", Sabah, 9 Haziran 1915, s. 4.

${ }^{71}$ Çanakkale Hatıraları, C: II, s. 41.
}

\section{Journal of History Studies}




\section{Kaynakça}

\section{I-Kitaplar}

AVŞAR, Servet- BABACAN, Hasan (Haz.), Miralay Süleyman Şakir, Cepheden Hatıralar Altıncı Fırka Çanakkale Harbinde, Vadi Yayınları, Ankara 2006

BABACAN, Hasan vd. (Haz.), Bolvadinli Mehmet Sinan Bey'in Harp Hatıraları Mehmet Sinan Özgen, İşbankası Yayınları, İstanbul 2011.

BABACAN, Hasan, "Enver Paşa", Türkler, C. 11, Yeni Türkiye Yayınları, Ankara, 2002, s.263-273.

CASSAR, George H., Çanakkale ve Fransızlar, (Türkçesi: Nejat Dalay), Milliyet Yayınları, 1. Baskı, Ankara, 1974.

Çanakkale Hatıraları, C: II-III, (Yayıma Hazırlayan: Metin Martı), Arma Yayınları, 1. Bask1, İstanbul, 2001.

HAMILTON, Ian, Gelibolu Günlü̆̆ü, (Çev: Osman Öndeş), Hürriyet Yayınları, 1. Baskı İstanbul, 1972.

JAMES, Robert Rhodes, Gelibolu Harekâtl, (Tercüme Eden: Halûk V. Saltıkil), Belge Yayınları, ilk Baskı, İstanbul Matbaası, İstanbul, 1967.

Kanlısırt Günlü̆̆̈̈ Mehmed Fasih Bey'in Çanakkale Anılarl, (Yayına Yazırlayan: Murat Çulcu), Kaptan Yayıncıllk, İstanbul, 2006.

MÜHLMAN, Carl, Çanakkale Savaşı, Bir Alman Subayının Anıları, (Tercüme: Sedat Ümran), Timaş Yayınları, İstanbul, 2006.

Münim Mustafa, Cepheden Cepheye, Ege Basimevi, C: I, İstanbul, 1940.

OGLANDER, C.F. Aspinall, Büyük Harbin Tarihi Çanakkale Gelibolu Askeri Harekatı, (Yayına Hazırlayan: Metin Martı), C: II, Arma Yayınları, 2. Baskı, İstanbul, 2005.

ÖZKÖK, Hidayet, Çanakkale'den Hicaz'a: Harp Hatıralart, Kayseri: İl Kültür Müdürlüğ̈̈ Yayınları 1. Baskı, Kayseri, 1992.

SAYILIR, Burhan, Selanikli Yüzbaşı Hüsnü Efendi'nin Çanakkale Muharebeleri Günlüğü, Grafiker Yayınları, 1. Baskı, Ankara 2014.

SÖZÜDEMIR, Ebral, Anzakların Gözüyle Çanakkale Savaşları, İstanbul Üniversitesi Atatürk İlkeleri ve İnkılap Tarihi Enstitüsü, Yayınlanmamış Yüksek Lisans Tezi, İstanbul, 2006.

TUNÇOKU, A. Mete, Anzakların Kaleminden Mehmetçik, Çanakkale 1915, Atatürk, Dil ve Tarih Yüksek Kurumu Atatürk Araştırma Merkezi Yayınları, Ankara, 2000.

TUNÇOKU, Mete - TAŞKIRAN, Cemalettin, Çanakkale, Churchill ve Anzaklar, Genelkurmay Basımevi, Ankara, 2000.

\section{II-Dergi Ve Gazeteler}

COŞKUN, Halise "Çanakkale Savaşlarında Sağlık Hizmetleri”, TAF Preventive Medicine Bulletin, Y1l: 2014, C: 13, S: 2, sy. 93-98. 
ÇEVIK, Mehmet \& ÇELOĞLU, Yavuz Selim, "Çanakkale Cephesi'nde Türk Ordusunun İaşe ve İkmal Faaliyetleri”, Çanakkale Araştırmaları Türk Yıllığı, Yı1: 13, S. 18, Bahar 2015, sy. 299-347.

ERAT, Muhammet “Çanakkale Savaşı'nda İaşe Problemi”, Çanakkale Araştırmaları Türk Ylllı̆gl, Y1l: 1, S: 1, Mart 2003, sy. 114-133.

ERDEMIR, Lokman, "Çanakkale Muharebeleri Sırasinda İstanbul'da Yardım Faaliyetleri”, Çanakkale Araştırmaları Türk Yıllı̆̆g, Yıl. 10, S. 12, Bahar 2012, sy. $35-60$.

ESENKAYA, Ahmet, "Çanakkale Muharebelerinde Cephede ve Cephe Dışında Sağllk Hizmetleri”, Çanakkale Araştırmaları Türk Yıllı̆̆ı, S: 10-11, sy. 25-70.

ÖZKAYA, Yücel, "Türk ve Dünya Basınında Çanakkale Savaşları”, Atatürk Araştırma Merkezi Dergisi, C. XIII, S. 34, Mart 1996, sy. 295-313.

SAYILIR, Burhan, "Çanakkale Savaşları'nda Yer Alan İtilâf Askerlerinin Dini-Etnik Yapıs1 ve Sahip Oldukları Türk İmajı", OTAM, (Ankara Üniversitesi Osmanlı Tarihi Araştırma ve Uygulama Merkezi Dergisi) S: 18, 2005, sy. 319-331

ULU, Cafer, "Çanakkale Muharebeleri Sırasında Basının Propaganda Aracı Olarak Kullanılması: Harp Mecmuası Örneğı”, Çanakkale Araştırmaları Türk Yıllı̆̆ı, Yıl. 10, S. 12, Bahar 2012, sy. 61-83.

YAZICI, Nevin, "Çanakkale Savaşı’nda Türk Kadınının Rolü”, Akademik Bakış, C. V, S. 9, Kış 2011, sy. 245-264.

YILMAZER, Tuncay, "Çanakkale Savaşlar'mda Sağlik Hizmetleri”, Çanakkale Savaşları Tarihi, C. IV, Değişim Yayınları, 1. Basım, İstanbul, 2008, sy. 2349-2355.

“Ahval-i Shhiye”, İkdam, 16 Temmuz 1915.

"Çanakkale Müdafilerine Müdafaa-i Milliye Cemiyetinin Hediyesi”, Tanin, 26 Şubat 1915.

“Çanakkale”, Servet-i Fünun, S. 1257, 25 Haziran 1331 (8 Temmuz 1915).

"Fevkalade Bir Müsamere”, Tanin, 2 Haziran 1915.

“Gazileri Ziyaret”, Sabah, 5 Mayıs 1915.

“Gazilerimiz İçin”, Sabah, 9 Haziran 1915.

“Gazilerimizi Ziyaret Hedâyâ", İkdam, 12 Mayıs 1915.

“Gazilerimizi Ziyaret”, Sabah, 11 Mayıs 1915.

“Kahraman Mehmet Çavuş İçin”, İkdam, 11 Mart 1915.

“Osmanlı Kadınlar Cemiyeti Hayriyesi”, Sabah, 18 Mayıs 1915.

Harp Mecmuast, Y1l: 1, S: 8, s. 128; S: 2, s. 32; S: 9, s. 144.

İkdam, 13 Mayıs 1915.

İkdam, 16 Temmuz 1915.

Sabah, 11 Mart 1915.

Sabah, 11 Mayıs 1915 
Sabah, 15 Mayıs 1915.

Sabah, 6 Mart 1915, s. 4.

Tanin, 10 Mart 1915. 